\title{
Narration of Lives and Nations
}

\author{
National Stereotypes in the Coverage of \\ World Cup Football in the Norwegian Channel TV2
}

\author{
Sharam Alghasi
}

\begin{abstract}
Iran was one of the participants in the 2006 football World Cup (WC) in Germany. A special WC programme on TV2, one of two primary Norwegian TV channels, entitled World Cup Studio (Norwegian: VM-studio), offered various reports for a Norwegian audience and was sent before and after each match along with a short segment of reportage from the countries involved. The present article focuses on one of the World Cup Studio programmes broadcast during the WC games between Iran and Mexico. The purpose of the article is to investigate how Iran and Mexico, as two national and cultural entities, are presented in relation to a Norwegian socio-cultural context. Additionally, the particular geopolitical condition at the time before the World Cup, as represented in these programmes, is identified and classified.
\end{abstract}

Keywords: Iran, Mexico, football, TV, intertextuality, narratives, representation

\section{Introduction}

In the present study, Iranian participation in the Germany '06 World Cup (WC) in football has been linked to media practices revealed in a case study of the national Norwegian media. Through this, I wish to highlight aspects of the media's processes of meaning production and differentiation of Iran as a nation as well as its portrayal of "Iranianess" as a static cultural identity.

On the one hand, just prior to the $2006 \mathrm{WC}$, there had been massive media focus on Iran and its nuclear dispute within the United Nations Security Council. In addition, Iranian President Mahmoud Ahmadinejad's alleged views concerning Israel had contributed to a tense attitude towards Iran within the Western public sphere. The media in 2006, as today, focused heavily on Iran as a country at the centre of geopolitical unease, and as a major threat to the world's peace and security. ${ }^{1}$

On the other hand, football is often seen as an important arena, involved in shaping and cementing national identities (Archetti 1994, Giulianotti 1999, Robertson 2001). Giulianotti, for instance, sees football as an instrument for focusing on "who we are", on the one hand, and "who we are not", on the other (Giulianotti 1999). In today's globalized media age, sporting events such as the WC or the Olympic Games are sometimes called "mega sport" events because of their ability to attract media professionals (Alabarces 2001). Dayan and Katz (1992: 1) call these media events "high holidays of mass communication" and suggest that a sense of collective identity is heightened 
when such occasions are broadcast. Hobsbawm states that "through mass spectacle of international contests sportsmen representing their nation or state became expressions of their imagined communities" (1992: 142). The technological power of mass media ensures that every corner of the nation can share in the action by watching the event on television. Within this context, television is one of several media sources that provide a concrete shape to the abstract notion of a nation.

The focus here is to look at how Iran and Iranianess as the other are identified, classified and represented within a Norwegian socio-cultural context as well as in relation to the geopolitical conditions surrounding Iran before and during the WC. Working at the interface between football and TV, the present article will explore the Norwegian media representation of Iran as nation and country and as a participant in the $\mathrm{WC}$, using as a case study a specific programme produced by Norway's VM-studio for the WC occasion.

\section{Media Representations and Narrations}

Benedict Anderson (1991) describes nations as "imagined communities" whose members do not know each other, but still have an image of a community. This description echoes Hall's position concerning the ability of national cultures to produce meanings about a "nation" with which we can identify. These meanings are, according to Hall, "contained in the stories which are told about it, memories which connect its present with its past, and images which are constructed of it" (1992: 293). In this regard, TV can be recognized as vital in providing images of communities and of what communities we are or are not a part of (Hall 1973, Bourdieu 1999). In this sense, TV has been characterized as a "story-telling machine," with a constant influx of narratives employed to make the constructed realities presented easier for viewers to comprehend (Nichols 1994). ${ }^{2}$

As media narratives often mirror power relations (Hall 1997, Gillespie 2006), Norwegian media narratives of meaning-making concerning Iran as a participant nation in the WC may be understood as discursive constructions used to describe and define 'Iranianess' as seen from an European or Norwegian point of view. Here, a distinction between Story and Plot is important (Grossberg 2006, Forster 1927, Chatman 1978, Gillespie 2006). ${ }^{3}$ The story is the actual development of events through time, what we see and hear, as well as what we deduce from what we see and hear. Plot, on the other hand, is the way the story is told (Forster 1927, Grossberg 2006). Narrative theory is thus primarily an analysis of plot and describes how a story is told in one way and not another (Grossberg 2006).

A narrative analysis of a VM-Studio programme suggests that there may be several discursive realities reproduced and represented by the Norwegian media in their plot concerning Iranian culture and everyday life. A filmmaker must have a story in order to create a certain plot (Bordwell \& Thompson 1990), and the turn from story to plot may be possible precisely because of pre-existing associations concerning Iran and Iranianess within Norwegian media. One is in an intertextual context in the sense that the story activates a series of different texts present in one's mental stock (Hall 1973, Fiske 1987), and thus is related to other cultural texts and pre-existing repertoires of knowledge. ${ }^{4}$

The $2006 \mathrm{WC}$ was the third time that the Iran national team had participated in a football WC tournament. ${ }^{5}$ Assuming a particular intertextual space surrounding Iran and Iranianess before and during the $\mathrm{WC}$, the task here is to examine the process by which these entities, Iran and Iranianess - in contrast to Mexico/Mexicaness or Norway/Nor- 
wegianess, as I will also discuss - were identified, differentiated and represented within the $V M$-studio during a particular programme. An examination of these choices may help us understand that meaning is constituted by differences and that we create meaning in the social world through processes of identification, differentiation, and representation.

\section{Methodological Design}

The present study uses discourse analysis to break down the media narratives in a $V M$ studio programme in order to identify representational patterns that underlie constructed narratives of the other. The focus is on the intersection between football as a global sport and media as a bearer of culture; the aim is to establish some understanding concerning how processes of identification and classification can emerge in these media practices.

The data for the study were selected from a programme broadcast by Norwegian TV2's VM-studio during the WC in 2006. ${ }^{6}$ VM-studio was the format constructed for broadcasting the matches, and it was broadcast on a daily basis and covered a large part of the TV2's schedule during the WC. ${ }^{7}$ The programme contained various components such as live broadcasts and reports from the matches, interviews, and match analysis. In addition, before each match in the preliminary round, two short film/documentaries from the involved countries were broadcast. These reports took the form of a "cultural trip" or "travelogue". An interview with the producer of VM-studio was conducted in which the purpose of using the "travelogue" format was explained: 8

"This was a WC with many 'new countries'. We wanted to see what football means for identity, to see if the game actually plays a bigger role than just being a game. Football, as we know, creates war - but can it also create peace and consolation?"

Thus, the reports were to provide audiences with greater knowledge of the societies behind the football teams.

The focus of the present article is on the VM-studio programme that presented the cultural trip to Iran and Mexico, taking place before these countries' first match in the preliminary round of the WC. Table 1 illustrates the different segments of the programme's contents:

Table 1. Content Overview for VM-studio on TV2 Channel, Broadcast $11^{\text {th }}$ of June 2006

\begin{tabular}{|c|c|c|c|c|}
\hline Parts & Theme & Purpose & Content & Length \\
\hline Part 1 & Report from Mexico & Football-cultural trip & Prologue & $1 \mathrm{~min} .55 \mathrm{sec}$. \\
\hline Part 2 & Discussion in studio & General football discussion & & $2 \mathrm{~min} .10 \mathrm{sec}$. \\
\hline Part 3 & Report from Mexico & Football-cultural trip & $\begin{array}{l}\text { Ordonez family } \\
\text { - Football in a restaurant }\end{array}$ & $6 \mathrm{~min} .58 \mathrm{sec}$. \\
\hline Part 4 & Report from Iran & Football-cultural trip & Rasoul in Bam & $5 \mathrm{~min} .40 \mathrm{sec}$. \\
\hline Part 5 & $\begin{array}{l}\text { Reports from earlier } \\
\text { matches }\end{array}$ & Analysis from other matches & & $7 \mathrm{~min} .12 \mathrm{sec}$. \\
\hline Part 6 & Report from Mexico & Football-cultural trip & A University football team & $3 \mathrm{~min} .10 \mathrm{sec}$. \\
\hline Part 7 & Report from Mexico & Football-cultural trip & (Repetition of part 1) & $1 \mathrm{~min} .55 \mathrm{sec}$. \\
\hline Part 8 & In studio & Program announcement & & $31 \mathrm{sec}$. \\
\hline Part 9 & $\begin{array}{l}\text { Main discussion before } \\
\text { the game }\end{array}$ & Pre-match reports & $\begin{array}{l}\text { Interviews with coaches } \\
\text { and players }\end{array}$ & $20 \mathrm{~min} .32 \mathrm{sec}$. \\
\hline
\end{tabular}


The focus of the present analysis is mainly on the programme's segments 1, 3, 4 and 6. Here, these programmatic segments, as will be described in more detail below, are considered to be those parts of the VM-studio programming that represented ideas and images of Iran/Iranianess. As Giulianotti points out, the binary oppositions in football help to explain how social identities are constructed in most societies (1999: 99). Thus, an analysis of the cultural trip to Mexico seems inevitable as the images and ideas on Iran/Iranianess in this programme were constructed and differentiated in comparison with Mexico/Mexicaness, as well as with Norway/Norwegianess.

The article examines various facets of this programme to explore how the stories on given social realities from Iran and Mexico were told within these cultural trips. Fairclough (1995) suggests that to understand media output, it is essential to investigate the ways in which the world is represented and in which identities are set up for those portrayed. The aim is then to explore the frames through which some parts of a given reality are selected and made more salient in the produced text. These frames "promote a particular problem definition, causal interpretation, moral evaluation, and/or treatment recommendation" as they describe the story (Entman 1993: 52). Here the rules and procedures for defining, recognizing, selecting, organizing, and presenting images and ideas on Iran and Mexico are in particular focus (Altheide 1987).

Accordingly, the study investigates a) how the worlds of Iran and Mexico are represented, meaning what actions, relationships, and identities were said to be at work in each given world. The focus on the latter is two-fold: it is both on actions, relationships, and identities claimed to exist independently in Iran and Mexico and on the actions, relationships and identities within Iran and Mexico, as these are linked to Norway and Norwegianess.

\section{A Story of Two Worlds: Iran and Mexico}

The VM-studio trips to Iran and Mexico claimed to link football and the $\mathrm{WC}$ to a portrait of everyday life in these societies. As illustrated in Table 1, the cultural trip to Mexico is given twice as much time as the trip to Iran (11.23 minutes for Mexico, and 5.40 minutes for Iran). In addition, the trip to Mexico contains several stories, while the trip to Iran is concentrated on a single story.

The trip to Mexico begins with images from ordinary life mixed with football-related images in Mexican society. The trip offers three different storylines: The first focuses on a football-loving family, the Ordonezes, who are followed by Norwegian TV reporters during a match between their favourite Mexican football team, Puma, and a main rival. We learn about the relationship the family members have to their beloved Puma, and how the everyday life of the family is organized in relation to their passion for football. The story ends with Puma's victory against the main rival, resulting in joy among the supporters, including the Ordonezes.

The second story contains a visit to a restaurant in Mexico where images from the restaurant are combined with an interview with the restaurant's chef. Everyday life at the restaurant - as well as public life in general - has been adjusted, because of the impact of the WC on Mexican everyday life.

The third part of the cultural trip to Mexico focuses on a student football team from an elite university in Mexico City. The main character of this part of the film is the team's 
coach, who is asked about the football activities of his team as well as the position of football in Mexican society.

As mentioned, the cultural trip to Iran focuses on a single story. Here, the focus is on an earthquake tragedy that occurred in Bam, an ancient and culturally significant city in South-eastern Iran, on December 26 2003, more than two and a half years prior to the football match between Iran and Mexico. In Bam we are introduced to Rasoul, a 14-year-old boy who has lost his entire family in the earthquake. Despite this loss, Rasoul, along with other boys like him, joins a football team in Bam, Bam 's Hope. The team eventually participates in the Norway Cup, a large international football tournament for youth between the ages of 10 and 16 in Norway. As suggested in the film, football and participation in the Norway Cup have become a very important part of the healing process for Rasoul and his team-mates. The story ends with a much brighter view concerning the sort of future that awaits Rasoul and his team-mates.

The portrayal of Iran, as presented, is limited to a single story, from a single place, while the trip to Mexico shows marked diversity in the representation. Can these forms of representation be seen as reaffirmation of a possible over-simplified image of Iran, and a possible less-simplified image of Mexico?

\section{National Plots: Framing the Worlds of Iran and Mexico}

Postcolonial theorist Homi Bhabha is concerned with ideas surrounding the nation as they are expressed in narrative form. He invites his readers "to study the nation through its narrative address" by investigating the different ways in which people "plot the narrative of the nation" (1990a: 3, 1990b: 294). The processes of identification and classification concerning the nations of Iran and Mexico are framed and introduced in the cultural trips to these countries. As will be discussed later, this is also the case for the nation of Norway.

As suggested, narrative is a story with a beginning, middle, and an end (Aristotle, in Meadow 2003). When events are expressed in narrative form, they are given "a structure, an order of meaning, which they do not possess as mere sequence" (White 1981: 25). The beginnings of the cultural trips to Iran and Mexico are keys to our examination of how the stories are framed. The analysis of this part of the trip reveals that certain pieces of realities in Iranian and Mexican everyday lives are selected out and made more visible in the text. During this part of the trip, particular themes for the trip, characters, and the settings for the actions they carry out, as well as particular causal relationships, are presented to viewers and suggest specific national identities.

$V M$-studio starts with a prologue that may be seen as the window to the main attraction of the day - the Iran-Mexico match, but this segment primarily offers a representation of Mexico. The prologue starts with a child on the street staring right into the camera, followed by several shots from ordinary life in Mexico, such as children playing, or an elderly Indian woman walking on the street, and so on. The shots move in slow-motion and slow background music accompanies the pictures. Suddenly everything changes; the music becomes more energetic and the shots move very quickly. Table 2 presents an overview of this trip.

Table 2 illustrates that the content of this trip presents a strong link between Mexican everyday life and football, where one can observe the presence of football in every aspect 
Table 2. List of Content for the Cultural Trip to Mexico (Representation of Mexican world)

\begin{tabular}{|c|c|}
\hline Actions/ Frame of action & Texts/interviews \\
\hline $\begin{array}{l}\text { a) A boy in a playground football goal area, b) an Aztec-inspired } \\
\text { hat covers the whole screen, c) an injured football player rolls on } \\
\text { a football ground, d) a football coach talks to his players in the } \\
\text { break of a game and shouts, "We have played a horrible game", } \\
\text { e) a little girl with her doll at her home, stares into the camera, } \\
\text { f) some young boys on the street wave to the camera, e) a worker } \\
\text { is at work, f) a young man sells flowers on the street, g) men and } \\
\text { women express their joy in the football stadium, h) a cheerleader } \\
\text { dances in the stadium }\end{array}$ & \\
\hline Personal interview & $\begin{array}{l}\text { - We have to watch football everyday } \\
\text { - This is a passion } \\
\text { - The first round it will be Portugal } \\
\text { - Football is passion } \\
\text { - This is adrenalin (football) }\end{array}$ \\
\hline Written text on the screen & $\begin{array}{l}\text { Mexico-Iran, Mexico-Angola, Mexico- } \\
\text { Portugal (after one another, covering the } \\
\text { whole screen) }\end{array}$ \\
\hline $\begin{array}{l}\text { a) People play football in parks and stadiums, b) statue of a na- } \\
\text { ked woman in a city square, c) feet of a dancer dancing an Indian } \\
\text { dance, d) people play football in a big public square, e) a girl } \\
\text { performs football tricks in a park, f) view of an Aztec temple from } \\
\text { distance, g) people play football in a park. }\end{array}$ & \\
\hline Written text on the screen & $\begin{array}{l}\text { People, emotions, football, Mexico } \\
\text { (Covering the whole screen). }\end{array}$ \\
\hline
\end{tabular}

of life: it's in the parks, on the streets, or at the football stadium. In the beginning, the interview objects emphasize similar ideas and further illustrate the Mexican passion for football. The importance of the WC is underscored, both by those interviewed, who see Portugal as the main rival in the first round, and by the texts covering the whole screen that announce Mexico's matches in the WC against Iran, Angola and Portugal. At the end, the message of "people, emotions and football" scrolled across the screen summarizes the intended frame for the Mexico trip - to link football to ordinary life, marked by a great amount of passion and adrenalin.

Other stories from the trip to Mexico are constructed and developed using this narrative. Following the prologue, we are taken to a football stadium. While presenting scenes from the stadium such as supporters with the flag of their beloved team moving toward the stadium, or beautiful cheering girls in the stadium dancing, a voice-over introduces us to Mexico and the Ordonez family:

There are not many things more important than football in Mexico. Here, people live and breathe football. Going to a football match is a family-happening for many Mexicans. The Ordonez family never misses one football match played by the football team of its heart, Puma.

These metaphors reaffirm the selected frame for the cultural trips to Mexico; that "people live and breathe football", and thus once again underline the importance of football among Mexicans. The programme personifies football and passion in the Mexican world by introducing us to members of a football-loving family, the Ordonezes. Later on, we are taken to a fashionable, gourmet restaurant in Mexico, where we are introduced to a chef, Federico. The camera moves around the restaurant and then focuses on him, with a voice-over explaining: 
This is Chef Federico. Federico has a problem. He is afraid that the World Cup will not be such a good time for business for his restaurant. The employees are very carefully chosen, but they are all football-crazy.

Here, the story moves the importance of football beyond the level of family and to the broader organization of everyday life. Mexicans are simply "football-crazy" and that has important consequences when managing a business. The VM-studio cultural trip to Mexico continues its focus on the nation's social structure in relation to football with a slightly more critical examination of football and broader society. The anchor notes, "Not everything in Mexican football is as it should be. One of the problems is the high wage for the players". We are then taken to "one of the most prestigious private universities in Mexico City" for a closer look at the relationship between football and Mexican economic structures.

While football in Mexico is framed as an integrated part of life that is marked by passion, the exposition of the trip to Iran suggests a different frame. The anchor in the studio presents the report from Iran:

Two and a half years have gone since the earthquake in the city of Bam took the lives of 35,000 people and left $85 \%$ of this Iranian city in ruins. In a gloomy everyday life, the local football team is a light and a source of optimism and belief in the future, not least for many of the players who have lost their loved ones.

The theme for the trip to Iran focuses on the Bam earthquake tragedy. The anchor presents a causal relationship in which football is suggested to lead to increasing "optimism and belief in the future" in the midst of tragedy. This causal link stands as the main plot of the cultural trip to Iran, and is framed accordingly; in the subsequent scenes of the cultural trip, the types of formative processes and the semiotic choices made support a link between football and the tragedy of Bam. Table 3 presents some major parts of this trip's exposition.

Table 3. List of Content for the Cultural Trip to Iran (Representation of Iranian world)

\begin{tabular}{l|l} 
Actions/ Frame of action & Texts/interviews/voice-over \\
\hline $\begin{array}{l}\text { A man sits at a grave in a graveyard. Sad traditional Iranian music } \\
\text { plays in the background. }\end{array}$ & Slow piano in the background \\
\hline $\begin{array}{l}\text { a) People pull the dead from the ruins of the Bam earthquake, } \\
\text { b) a man sits and cries in the ruins while others try to help him/ } \\
\text { stop him, c) shots taken by helicopter demonstrate the massive } \\
\text { destruction of the city, d) another man sits on the ruins hitting } \\
\text { himself (all of the scenes from a-d are cuts from the time of } \\
\text { earthquake), e) shots are taken from a car while driving and show } \\
\text { massive ruins everywhere in the streets of Bam, as it currently } \\
\begin{array}{l}\text { exists, f) scenes from a graveyard, g) paintings of casualties from } \\
\text { the Bam tragedy are displayed alongside written verses from the } \\
\text { Koran, h) a close-up of a painted picture, again alongside written } \\
\text { Koranic verses. }\end{array}\end{array}$ & $\begin{array}{l}\text { Mixed sounds from different news cuts } \\
\text { quake reports fime of the earth- }\end{array}$ \\
\hline $\begin{array}{l}\text { A 3- or 4-year-old boy climbs up the ruins of the earthquake. } \\
\text { Once reaching the top he looks around }\end{array}$ & $\begin{array}{l}\text { Voice-over: } \\
\text { The earthquake in Bam for two and a } \\
\text { half years ago left the most of the city } \\
\text { in ruins. }\end{array}$ \\
\hline $\begin{array}{l}\text { A Norwegian female reporter with headscarf and manto with a } \\
\text { graveyard in the background. }\end{array}$ & $\begin{array}{l}\text { Reporter notes: } \\
\text { "Over 35,000 victims of the earthquake } \\
\text { are laying in this graveyard, among them } \\
\text { Rasoul's family." }\end{array}$ \\
\hline
\end{tabular}


These segments establish a frame in which the tragedy of Bam links football and Iranian ordinary life. The texts indicate the tragedy's outcomes: ruins, death, and misery. Rasoul, a 14-year-old boy, is the main character within this frame and personifies the tragedy of Bam - he is the face of Iran for VM-studio viewers.

The beginning parts of the cultural trips to Iran and Mexico illustrate the relation between football and everyday life in these two countries. This link, however, leads to two different processes of plot construction: while in Mexico football is an integrated part of everyday life, in Iran football functions "as a source of optimism and belief in the future". While one trip revolves around the joy of life, the other revolves around the tragedy of life.

The frames, images, voice-overs, texts, and interviews all support the choices made in the processes of establishing the purposes and points of view of the ensuing cultural trip. In Iran, death, tears, grief, ruins, and graveyards function paradigmatically; they are elements supporting the syntagmatic organization, the plot. They also function metaphorically to illustrate the tragedy in Bam, to make the tragedy comprehensible. The chosen elements in Mexico are different; the Latin temperament, the passion, the joy, the popularity of the game, the Ordonez family, all support a different purpose that seems to be at work on both the paradigmatic and the metaphoric level. Paradigmatically, these elements support the idea of joy promoted by football among the Mexican community. Metaphorically, enthusiastic people at a stadium or an angry, strongly emotionally involved coach by the sideline function as metaphors for the Mexican quality of being passionate.

\section{The Story Continues: Cultural Affinity}

Thus far, we have focused on the frames through which the worlds of Iran and Mexico are represented. In this section, I move further into the cultural trips in order to look at the actors, the relationships they are in, and the identities they symbolize. Table 4 illustrates these elements with the trip to Mexico:

Table 4 illustrates several eye-catching elements in this constructed Mexican world and the identities within this world. These elements are located throughout the cultural trip to Mexico and together indicate the constructed Mexican "we".

One element is linked to the family institution. Family values are often defined as good values, because they say something about a normal way of life in a given culture. As seen in Table 4, the togetherness of the family is reaffirmed by semiotic choices and is well represented in all segments: Aureli was at a football match for the first time when her mother was pregnant with her, and the Ordonez father is the leader of a group of football supporters. The Ordonez family represents the togetherness of the Mexican identity and football serves as a metaphor for this unity. This element of togetherness is also traced through representations of football in different places throughout the trip; in a park people play football together or the supporters together cheer their team, and so on.

A second element is the joy of life in Mexican society. Mexicans seem to be a very happy people: they dance and laugh throughout the cultural trip. The Ordonez family personifies this: Puma's victory leads to great joy for both the family and other supporters. Like the Ordonez family is represented as together and happy by VM-studio, so is the rest of the Mexican world. 
Table 4. List of Contents for Cultural Trip to Mexico (Actions, relationships and identities)

\begin{tabular}{|c|c|}
\hline Actions/ Frame of action & Texts/interviews/voice-over \\
\hline $\begin{array}{l}\text { Children and women, and other supporters are at the } \\
\text { stadium; they talk, they laugh, they buy flowers, cheer } \\
\text { girls dancing }\end{array}$ & $\begin{array}{l}\text { Voice-over: } \\
\text { - Going to a football match is a family happening for } \\
\text { many Mexicans. The Ordonez Family never misses } \\
\text { a football match, the team of their heart, Puma, is } \\
\text { playing. }\end{array}$ \\
\hline Ordonez (The daughter- Aureli) interviewed: & $\begin{array}{l}\text { - This is something the family has done since I was } \\
\text { a little girl (going to a football match). It is normal for } \\
\text { us to be in the stadium and to be with Puma. }\end{array}$ \\
\hline \multirow[t]{2}{*}{ Ordonez father, Memo, interviewed } & $\begin{array}{l}\text { - The Sombrero (he is wearing) is something beauti- } \\
\text { ful, like an amulet. }\end{array}$ \\
\hline & $\begin{array}{l}\text { Voice-over: } \\
\text { - Aureli is with her parents Rosalinda and Memo. } \\
\text { Once again they are ready for a match. It has been a } \\
\text { long time since Aureli's first Puma match. }\end{array}$ \\
\hline $\begin{array}{l}\text { Ordonez (The daughter- Aureli) interviewed in } \\
\text { stadium: }\end{array}$ & $\begin{array}{l}\text { - The first time I was at a Puma match was when my } \\
\text { mother was pregnant with me. }\end{array}$ \\
\hline $\begin{array}{l}\text { Ordonez (The parents-Memo and Rosalinda inter- } \\
\text { viewed in stadium: }\end{array}$ & $\begin{array}{l}\text { Journalist: Real Puma supporter, hey? } \\
\text { Memo: Yes, } \\
\text { Rosalinda: Si. Claro! (laughing together with Aureli) }\end{array}$ \\
\hline $\begin{array}{l}\text { Aureli and Rosalinda in the stadium with a Puma flag. } \\
\text { Memo and other supporters preparing for the match, } \\
\text { putting the flag up in the right place and so on. }\end{array}$ & $\begin{array}{l}\text { Voice-over: } \\
\text { - Memo is a teacher at the university, but on Sun- } \\
\text { days he is a leader of his own (football) supporter } \\
\text { group where members are relatives and friends. }\end{array}$ \\
\hline
\end{tabular}

The third element in the segments and in the rest of the trip is the existence of wealth in Mexican society. Memo, the Ordonez family patriarch, is a university professor, a probable indicator that, in terms of private economy, he is no in immediate need. Those around him do not show any need either. Mexicans do well: they are together, they are happy, and they seem to be wealthy. Scenes at a fashionable gourmet restaurant and at the "most prestigious private university" further underscore the focus on a wealthy Mexico.

The fourth element is the usage of well-known Mexican traditional/religious symbols. Memo sees a sombrero, a traditional Mexican hat, as "an amulet"; this indicates the strong thread of traditional culture that runs through everyday life and football. In rapid scenes, various metaphors of Mexican symbols are shown: a sombrero, an ancient Mayan temple, or Indians dancing on a stadium or on the street. These symbols lend an exotic touch to the Mexican portrait.

The fifth element is the position of women in the cultural trip to Mexico. Women are active when they are in the stadium as spectators or when they are in a park playing football with their children. Aureli shows her football ability to the reporters, female cheerleaders in the stadium are shown again and again, and cameras pass the square with the statue of a naked woman located in the middle, indicating that women hold a liberal position in Mexican society.

These elements may be seen as paradigmatic units and often emerge together in the construction of Mexican everyday life, and consequentially in the construction of Mexican identity. These paradigmatic units stand as cultural qualities often praised and valued in Norwegian society as well, and combined with an exotic image of the society, create a frame that is easy for a Norwegian to associate with his/her own life in Norway. 
The world of Iran, and the cultural quality recreated in the VM-studio trip to Iran, is different. If happiness and wealth surround the Mexican world, then the world of Iran is constructed around sadness, poverty and ruins. Table 5 provides an overview of these elements.

Table 5. List of Contents for Cultural Trip to Iran (Actions, relationships and identities)

\begin{tabular}{|c|c|}
\hline Actions/ Frame of action & Texts/interviews/voice-over \\
\hline $\begin{array}{l}\text { Rasoul sitting at what once was his house. The } \\
\text { camera moves from one side to another and there is } \\
\text { nothing but ruins around him. The camera then pans } \\
\text { to the whole house. }\end{array}$ & $\begin{array}{l}\text { Voice-over: } \\
\text { - This was the home (referring to the ruins of Ra- } \\
\text { soul's house at the background) of fourteen-year-old } \\
\text { Rasoul who lost his parents and five of his brothers } \\
\text { and sisters in the earthquake. (...)The young boy still } \\
\text { has great problems talking about his tragedy. }\end{array}$ \\
\hline $\begin{array}{l}\text { Rasoul interviewed. He points at a frame on the wall, } \\
\text { with a few pictures on it. Then the camera zooms on } \\
\text { pictures of Rasoul's family. }\end{array}$ & $\begin{array}{l}\text { - This is my father, this is my mother, this is my sister } \\
\text { and this is my brother. }\end{array}$ \\
\hline $\begin{array}{l}\text { The voice-over introduces us to Said Poya, an Iranian- } \\
\text { Norwegian, as one who has been engaged with the } \\
\text { victims of the tragedy, and has been a great supporter } \\
\text { for Rasoul. He is now interviewed. He talks about } \\
\text { Rasoul's condition after the earthquake: }\end{array}$ & $\begin{array}{l}\text { - After the earthquake he was very depressed. For a } \\
\text { long time, he didn't talk to anyone. He was quite. He } \\
\text { never smiled. }\end{array}$ \\
\hline Rasoul plays football somewhere in Bam & $\begin{array}{l}\text { Voice-over: } \\
\text { - In this difficult situation football has become a } \\
\text { rescue for the fourteen-year-old boy (Rasoul). The } \\
\text { Bam team, Bam's Hope, was established and has } \\
\text { gathered fifteen boys who all share Rasoul's fate. } \\
\text { Together they use football and each other to work } \\
\text { through their grief. }\end{array}$ \\
\hline
\end{tabular}

The first segment in Table 5 introduces us to the main character of the trip to Iran, Rasoul. While introducing Rasoul, the screen is covered with the ruins of his house. In the next segment, the Norwegian-Iranian figure, Said Poya, steps in and tells viewers of Rasoul's miserable life, which has been caused by the earthquake. The voiceover in the third segment confirms the total disaster within which Rasoul and many of his peers have found themselves after the earthquake. The concluding message illustrates how Rasoul and his friends "use football and each other to work with their grief".

The paradigmatic units shown in Table 5 illustrate a strong contrast to those described in the trip to Mexico. Here, happiness and joy are substituted with massive sorrow and grief. The togetherness represented by the Ordonez family is substituted with the solitude of Rasoul and all of the other boys his age who have lost family members. Mexico's wealth is substituted with poverty. Whereas skyscrapers are visible around the football ground at the university when we are shown this elite institution in Mexico, in Bam there are no buildings left and people live simply in ruins. When they play football, they play under very poor conditions. In addition, strikingly, there are almost no women in the trip to Iran, as if women have left the town. The scenes, therefore, seem to lack the cross-gender interaction seen in the trip to Mexico, and the absence of women in the trip to Iran does not bode well for the position of women in Iranian society. Most notably, the cultural and traditional signs in the trip to Iran are strongly linked to religious, and more specifically, Islamic signs, as these symbols are known in the Western or Norwegian socio-cultural context. A Norwegian female reporter in the opening part of the trip 
to Iran (see Table 3) wears hijab, indicating that women in Iran are not allowed to wear normal clothing, and instead must follow Islamic codes of dressing. A scene in a grave yard focuses on Koran verses written on banners; these verses accompany the pictures of death and hang in the air in the graveyard area.

$V M$-studio's process of defining, recognizing, selecting, organizing and presenting images and ideas of Iran and Mexico indicates that there are differing distances from Norway and Norwegian culture to the cultural qualities represented for the Mexican and Iranian societies. The programme suggests that there is a greater cultural affinity between Norway and Mexico/Mexicaness than between Norway and Iran/Iranianess. Scenes of family togetherness and passion in Mexico are more familiar to the Norwegian socio-cultural context than are scenes of Iranian solitude, ruin, and religious zealotry. These presented identities awaken two different pre-existing meaningful texts within a Norwegian socio-cultural context.

\section{The Norwegian "Helping Hand" at Work}

While this analysis has focused on the represented worlds of Iran and Mexico, and associated actions, relationships and identities, I now shift focus to the ways in which Norway and Norwegianess are represented during the cultural trips to Iran and Mexico. Whereas in Mexico football is a metaphor for celebration, a means to further enjoy an already happy life, in Iran, football serves as a metaphor for rescue, a means to move away from the tragedy, death, ruin and sorrow. Norwegian plot elements are key to this metaphor.

The trip to Iran is about to come to an end, and a voiceover provides additional details concerning the Rasoul's team mates. The camera pans in slow motion over the boys and explains that together they have lost 132 members of their families in the earthquake. Football provides a way out of depression and grief for Rasoul as well as for other the team members and coach, and most notably, their invitation to the Norway Cup was a turning point for Rasoul and rest of the team. ${ }^{9}$ Table 6 presents the scenes in which Norway plays a role in the cultural trip to Iran:

Table 6. List of Contents for Cultural Trip to Iran (Norwegian helping hand)

\begin{tabular}{l|l} 
Actions/ Frame of action & Texts/interviews/voice-over \\
\hline Scenes from a football ground with children playing & $\begin{array}{l}\text { Voice-over: } \\
\text { Before the earthquake many of the boys had not } \\
\text { crossed the border. Therefore, they were full of joy } \\
\text { when they were permitted to travel to Norway and } \\
\text { participate in Norway Cup and play real football (...) } \\
\text { the football trip to Norway during the summer of last } \\
\text { year was a turning point for Rasoul. }\end{array}$
\end{tabular}
have become great role models for other earthquake victims. Now those who want to play football are urged to become members of the team. The city has a long way to go, but Bam's football boys have their smiles back and have become a source of inspiration for many after that tragic catastrophe.

Two boys from Bam Hope's. They are asked about their experiences during the trip to Norway.
- the football grounds lying next to each other - the weather was very different compared to here," and that "it rained a lot... it was a very nice trip, and people were very kind." 
The content of the table underscores the importance of the trip to Norway in Rasoul's life and to the other members of Bam's Hope. The kids had never before played "real football", yet with the help and assistance of Norway and Norwegian humanitarian agents, the condition of misery and hopelessness has been transformed to a feeling of hope, as the football team is also called thereafter. While Norway does not participate in the WC, Norway/Norwegianess is implicitly recounted in the narration of Iran and Rasoul's life. In fact, Norway/Norwegianess creates a needed positive counterbalance in the narrative by giving Rasoul and his friends a helping hand and an opportunity to move on with their lives.

In this constructed narrative on Iran, Norway is portrayed as an agent of humanity, a position described by Tvedt (2003), who employs the term "Regime of Goodness" to refer to Norwegian foreign policy in relation to undeveloped countries. This policy is heavily influenced by an ideology in which the world is divided into the bad and the good, the strong and the weak, and the powerful and the needy, where the Norwegian aim is to help and support those who are weakest or poorest. This perspective concerning third-world politics, with its particular structural relation between Norway and the world outside, has created a unique and powerful national identity and has actively distinguished between Norway and the world beyond (Tvedt 2003). The existence of this "Regime of Goodness" as a pre-existing discourse in the Norwegian socio-cultural context produces, in part, the intertextual quality that exists in the reproduction and representation of Norway/Norwegianess in VM-studio programming.

Norway/Norwegianess is represented in quite different ways in the trip to Mexico. In Mexico, Norway does not represent a helping hand, but rather serves as a metaphor for leadership, beauty, and creativity, as illustrated through the creativity of a MexicanNorwegian chef at a restaurant in Mexico. These elements are supported through scenes in which the chef tries to administrate his restaurant's activities during the WC. Although the chef does not speak any Norwegian, he picks up some words used by the journalist. The different representation of Norway in relation to Iran and Mexico indicates different ways of positioning Norway/Norwegianess in relation to the two other countries and societies, where the cultural affinity between Norway and Mexico is reaffirmed, while the distance between Norway and Iran/Iranianess is once again underscored.

\section{Discussion: No sign of Mohammad, the Iranian Cookie Baker!}

The processes of identification, classification, and represention of Iranian and Mexican societies suggest the intertextual space surrounding these two countries as national and cultural entities. In the Norwegian socio-cultural context, the intertextual repertoires regarding Iran and Mexico differ, and the work of identifying and classifying leads to the construction of two different universes that are counterpoised differently in relation to Norway and Norwegianess (See appendix). ${ }^{10}$ Within the Norwegian context, football plays an important role in press coverage from Latin America, and is often portrayed with a passionate and exotic dimension (Sæther 2007). As one Norwegian programme has noted, passion and the exotic are believed to be "very much the chemistry of Latin American Football", and football "create[s] emotions second to none and a reputation amongst soccer 'aficionados' as the best in the world". ${ }^{11}$ The cultural trip to Mexico builds on similar metaphors; it reshapes pre-existing notions about Mexico. The con- 
struction of the trip to Mexico is about constructing a causal relationship in which football, passion, and a healthy everyday life go together. There is no room in this picture for a representation of the poverty, social injustice, or politicized aspects that may also represent living conditions in Mexico, conditions that may be less approachable for the Norwegian nation. ${ }^{12}$

To be sure, Mexico possesses a different position on the geopolitical scene compared to Iran. News related to Latin and South America is less and less prioritized in the Norwegian press (Sæther 2007). Issues related to the Middle East, however, often receive a great amount of attention by Norwegian media (Nohrstedt 2001, Eide 2008). While Mexico is more mentioned in relation to football, the exotic, and beautiful, Iran is more frequently linked to the uneasy categories of war, invasion, attack, human rights, terrorism, and sanctions. The presence of Iran as a source of tension was dramatically confirmed after the events of September $11^{\text {th }}, 2001$, when U.S. President Bush described Iran as a member of the "Axis of Evil". A new climax was reached by 2006 when Iran drew huge international attention from Western media because of its nuclear programme, as well as its alleged support of international Islamist terrorism. In fact, just before the '06 WC, several commentators argued for a sanction of the Iranian national team from the games. ${ }^{13}$ This discursive situation was also a predominant theme in the Norwegian media: in a headlining article on the $12^{\text {th }}$ of January 2006, just days before the WC, Dagbladet, one of Norway's primary newspapers, had the following to say about the geopolitical concerns related to Iran:

The conflict between Iran and the world, and particularly the Western world, is increasing. Iran's decision to keep enriching uranium is serious (...) the world is dealing with a regime that plays a main role in the game of controlling the chaotic Iraq.

This dominating media discourse concerning Iran was strongly linked to the geopolitical issues involving Iran. Top reports concerning Iran described 40,000 Iranian suicide attackers who were training in Iran and were preparing for attacks on Western targets (NTB 19.02.2006) as well as 11,000 rockets provided to Hezbollah by Iranians (Radio P4 16.07.2006).

The nation of Iran also stands as a strong symbol of Islam: in the post 9/11 era, critiques of Islam have been brought into the centre of attention in socio-cultural and geopolitical debates. Islamic values have been differentiated from "our values", which the viewer is left to infer are indisputably superior (Hedetoft 2003, Eriksen 2001). Debates focus mainly on the protection of "our values", associated with Christian, Western, and European liberalism, and contrast "our values" with values seemingly representative of Islamism, such as isolation, segregation, and the suppression of women (through veiling, among other practices), as well as the power of religious as opposed to secular values (Grillo 2004: 17).

$V M$-studio's organization of its cultural trips to Iran and Mexico illustrates the Norwegian perception of self; the representations of Iran and Mexico within the analysed cultural trips provide a location for the constitution and reproduction of the differing dominant cultural and political ideas and images related to Iranian and Mexican identities. Ideas and images concerning Norway and Norwegianess are employed to demonstrate a measurable distance from Iranian and Mexican nations and cultures. In 
this system of measurement, Mexico is understood and represented as more like "us," Norway and Norwegianess. Although Norway and Mexico are not very similar countries, "our" values are presented as corresponding to Mexican values through the football.

From a Norwegian and Western socio-cultural space, as well as within the geopolitical scene that surrounded Iran at the time of the WC, it is hardly surprising that the meaning production concerning Iran in VM-studio programming was not simply a matter of a cultural trip aimed at constructing a picture of the relationship between football and life in Iran. The programme does not construct an enemy picture of Iran, and seemingly concentrates on the life of a group of children. However, even on such an occasion, celebrating a global sporting event, a different narrative construction of Iran, while seemingly impossible given these cultural and political assumptions, would have stood in great contrast to what seems to have been the dominating views and images of Iran during this time. ${ }^{14}$

Iranian-American stand-up comedian Maz Jobrani has aptly described this situation. ${ }^{15}$ He wonders whether it would ever be realistic to think that a TV team could travel to Iran and interview a smiling cookie baker named Mohammad, who only bakes cookies and is not connected with all negative associations surrounding Iran and Iranianess. Jobrani portrays a hypothetical report in which Mohammad, the cookie baker, says: "Hello, my name is Mohammad and I am baking cookies", and the reporter simply turns to the camera and says "that was the report from Tehran, back to you Bob". Jobrani maximizes the wry humour of this scene by playing on its seeming unlikeliness; this scene indicates the incredible difficulties one finds in the current media and political context regarding Iran and Iranian society. The VM-studio cultural trip represents this tension and the inability of mainstream Norwegian media to move beyond the impulse to reproduce limited and limiting notions of Iranian culture.

\section{Notes}

1. Much of the massive media content focused on Ahmadinejad in 2005 and 2006 centred on his anti-Israeli views. Ahmadinejad's quotation "Israel should be wiped off the map" was frequently used in describing his world views. In fact, Ahmadinejad never uttered this phrase, but had appropriated a phrase from a speech by the Ayatollah Khomeini from some years back, in which Khomeini suggested that "the occupation regime over Jerusalem should vanish from the page of time." This important nuance, however, was subsequently dismissed by most of the media. For more on this misinterpretation, see http://www. juancole.com/2006/05/hitchens-hacker-and-hitchens.html.

2. Narratives describe the act of telling a story (Grossberg 2006) and are constructed of "a chain of events in cause-effect relationship occurring in time and space" (Bordwell \& Thompson 1990:55).

3. There are various distinctions and terms regarding story and plot. Grossberg (2006) and Chatman (1978) employ the term Discourse. Forster (1927), Gillespie \& Toynbee (2006) and many others, on the other hand, use the term Plot.

4. It is recognized here, however, that intertextuality refers to the active creation of new texts from the dialogical interplay between texts and stored narratives. As Bordwell and Thompson have pointed out "a filmmaker in a sense turns the story into plot, while the viewers turn the plot into story" (1990:57). The present view acknowledges the need to link production and reception in this process of meaningmaking (Silverstone \& Georgiou 2005:434). The study deals exclusively with the production of the plot represented in the programme under focus. Upcoming studies, however, will focus on more active aspects of viewer reception.

5. Iran had previously participated in the World Cup in 1978 and 1998.

6. Norwegian TV2 was the major World Cup channel during the Germany 2006. Right before the World Cup, TV2 had long-term plans for establishing itself as the leading football channel in Norway, especially in competition with another nationwide Norwegian TV channel, NRK, and in this regard, their coverage was considered very important. For TV2, this coverage was a step towards establishing its strategic position in the market, as well as an economical opportunity to assure itself of new revenues 
by increasing its market shares. After a tough contest, a Nordic consortium including Swedish SVT and TV4, Norwegian TV2 and NRK, Danish TV2 and DR, and Finnish Yle together bought the rights from Infront Sport\&Media, which in turn had bought the rights from FIFA. In Norway, two-thirds of the matches were broadcast by TV2 (42 matches) and the remaining one-third ( 22 matches) were broadcast by NRK. Regarding the matches broadcast by TV2, the more attractive matches were broadcast by the principal channel, TV2, while less attractive matches were broadcast by a local TV2 channel branch, called TV2-Zebra (information provided by the "information section" at TV2).

7. The final match of the World Cup, broadcast by TV2, had 1.3 million viewers (a market share of $81 \%$ ), representing a huge number among a total population of 4.6 million Norwegians. Iran's matches against Mexico were viewed by 90 thousand, the teams matches against Portugal by 205 thousand (against Portugal), and the team's matches against Angola by eight thousand. Considering that the match against Mexico was broadcast by TV2 Zebra, netting 90 thousand viewers was a considerable feat.

8. The interview with the producer of the programme was conducted by email exchange. The producer was then asked about the aim of the programme format.

9. Norway Cup is held for youngsters between the ages of 10 and 16 every summer in Oslo.

10. The Appendix provides a comparison of the portrayal by the Norwegian press (radio, TV and newspapers) of several selected categories for Iran and Mexico since 1990. The data are selected from Norwegian A-tekst and indicate how Iran and Mexico are mentioned in relation to the chosen categories.

11. Introduction to the DVD film "Champions of the World", which focuses on Latino and South American football.

12. According to World Bank in 2002, half the population of Mexico was living in poverty and one fifth was living in extreme poverty. See: http://web.worldbank.org/WBSITE/EXTERNAL/COUNTRIES/LACEXT/MEXICOEXTN/0,,contentMDK:20233967 pagePK:141137 piPK:141127 theSite PK:338397,00.html

13. Angelika Beer, a Green member of the European Parliament, said: "A country with such a president, who is driving the country into isolation, has nothing to do at the World Cup." (Aljazeera $18^{\text {th }}$ of December 2005). But Sepp Blatter, the FIFA president, refused to get involved into any political wrangling, or "to enter into any political declarations (against Iran)..." (Aljazeera $18^{\text {th }}$ of December 2005).

14. The Iranian Football Federation was established in 1920, and over 100,000 people gather in a football stadium to watch club matches in the country (http://www.the-afc.com/eng/nassoc/country.jsp_IRN279-1.html). These facts could indicate a normal relationship towards football in Iran. This normal relationship was not a chosen theme for VM-studio, as poverty was not the theme in the representation of football in Mexico.

15. The comment made by Jobrani may at first glance be seen as a description of the American context regarding Iran and Iranianess. This article, however, emphasizes the global impacts of the cultural and geopolitical relevance of the constructed images of Iran and Iranianess. It is also worth mentioning that in 2000, a popular TV programme called "Gutta på tur" travelled to Iran, once again a cultural trip. In this trip, a "Caviar man" was interviewed, and asked about his profession. However, this programme was produced during the time when Mohammad Khatami was the president of Iran, known for being reformist, a time when many actors in the international community spoke warmly of establishing a dialogue and exchange with Iran. In my view, this is a reaffirmation of the interplay between cultural and geopolitical conditions influencing the narrative constructions on Iran and Iranianess.

\section{References}

Alabarces, P.; Tomlinson, A.; Young, C. (2001) 'Argentina versus England at the France '98 World Cup: Narratives of Nation and the Mythologizing of the Popular', Media, Culture \& Society 2001, 23; 547.

Aljazeera TV: $18^{\text {th }}$ of December 2005.

Altheide, D.L. (1987) 'Ethnographic Content Analysis’, Qualitative Sociology, 10(1), Spring 1987.

Anderson, B. (1991) Imagined Communities: Reflections on the Origin and Spread of Nationalism, revised ed. London: Verso.

Archetti, E. (1994) 'Argentina and the World Cup in Search for National Identity', pp. 37-63 in J. Sugden and A. Tomlinson (eds) Hosts and Champions: Soccer Cultures, National Identities and the USA World Cup. Aldershot: Arena/Ashgate.

Bhabha, H.K. (1990a) 'Introduction: Narrating the Nation', in Bhabha, H.K. (ed.) Nation and Narration, pp. 1-7. London: Routledge.

Bourdieu, P. (1999) On Television. Location: The New Press.

Bordwell, D.; Thompson, K. (1990) Narration in the Fiction Film. Madison, WI: The University of Wisconsin Press. 
Chatman, D. (1978) Story and Discourses. Ithaca, NY: Cornell University.

Dayan D., Katz, E. (1992) Media Events: the Live Broadcasting of History, Cambridge, Mass: Harvard University Press.

Eide, E; Simonsen, A.H. (2008) Verden skapes hjemmefra. Pressdekningen av den ikke-vestlige verden 19022002. Unipub.

Entman, R.M. (1993) 'Framing: Toward Clarification of a Fractured Paradigm', Journal of Communication, p. 51-58, 43(4) autumn 1993.

Eriksen, T.H. (2001) Bak fiendebilde. Oslo: Cappelen forlag.

Faireclough, N. (1995) Media Discourse. London: Edvard Arnold.

Fish, S. (1976) 'Interpreting the Variorum', Critical Inquiry Journal, University of Chicago.

Fiske, J. (1987) Television Culture. London: Methuen.

Gillespie, M.; Toynbee, J. (2006) Analysing Media Texts. Open University Press

Giulianotti, R. (1999) Football, A Sociology of the Global Game. Cambridge, Policy Press.

Grillo, R. (2004) Backlash Against Diversity? Identity and Cultural Politics in European Cities. University of Sussex.

Grossberg, L.; Wartella, E.; Whitney, D. Charles; Wise, J. Macgregor (2006) Media Making. Mass Media in a Popular Culture. $2^{\text {nd }}$ ed. SAGE Publications

Hall, S. (1992) 'The Question of Cultural Identity', pp. 273-325 in S.Hall, D. Held and T. McGrew (eds) Modernity and its Futures. Cambridge: Polity Press and Open University Press.

Hall, S. (ed.) (1997) Cultural Representations and Signifying Practices. Sage Publications.

Hedetoft, H. (2003) 'Cultural Transformation: how Denmark Faces Immigration', Open Democracy: 1-5.

Jensen, K.B. \& Jankowski, N.W. (1991) Five Traditions in Search of the Audience', The European Journal of Communication, vol. 5, 1990 pp. 207-238.

Longarce, R.E. (1974) 'Narrative versus Other Discourse Genre', in Brend, R.M. (ed.) Advances in Tagmemics. Amsterdam, North-Holland Pub.Co., pp. 357-376.

Meadows, M.S. (2003) Pause \& Effect: The Art of Interactive Narrative. Indianapolis, IN: New Riders.

Nichols, B. (1994) Blurred Boundaries. Questions of Meaning in Contemporary Culture. Indiana University Press. Bloomington and Indianapolis.

Nohrstedt, S.A. \& Ottosen, R. (ed.) (2001) Journalism and the New World Order. Gulf War, National News Discourses and Globalization. Göteborg: Nordicom.

Norwegian Radio P4: 16.07.2006.

NTB (Norwegian News Agency). 19.02.2006.

Robertson, A. (2001) 'Us, Them and Television News Narratives; Constructing Europe in TV News Broadcasts'. Paper presented at the Narrative, Identity and Order Conference at the University of Tampere, 13-15 September 2001.

Sæther, A.K. (2007) Rapporter fra bakgården. Norske avisers dekning av Latin-Amerika fra 1902 til 2002.

Silverstone, R. \& Georgiou, M. (2005) 'Editorial Introduction: Media and Minorities in Multicultural Europe', Journal of Ethnic and Migration Studies Vol. 31, No. 3, pp. 433-441.

Todorov, T. (1977/71) The Poetics of Prose (trans. R. Howard), Ithaca, NY, Cornell University Press

Tvedt, T. (2003) Utviklingshjelp, utenrikspolitikk og Makt. Den norske modellen. Gylendal Akademisk.

White, H. (1981) 'The Value of Narrativity in the Representation of Reality', in W.J.T. Mitchell (ed.) On Narrative, pp. 1-23. Chicago: University of Chicago Press.

Williams, L. (1993) 'Mirrors without Memories: Truth, History and the New Documentary', Film Quarterly, Vol. 46, No.3, Spring 1993:12,

http://www.the-afc.com/eng/nassoc/country.jsp_IRN-279-1.html

http://web.worldbank.org/WBSITE/EXTERNAL/COUNTRIES/LACEXT/MEXICOEXTN/0, contentMDK: 20233967 pagePK:141137 piPK:141127 theSitePK:338397,00.html

SHARAM ALGHASI, Dr.polit., Researcher, Department of Social Anthropology, University of Oslo, sharam.alghasi@sai.uio.no 


\section{Appendix}

Norwegian Media Focus on Iran and Mexico (some selected categories)

\begin{tabular}{llrrrrrr} 
& & \multicolumn{7}{c}{ Year } \\
Theme & Country & 1990 & 1994 & 1998 & 2002 & 2006 & Total \\
\hline Football & Iran & 18 & 27 & 283 & 61 & 339 & 1941 \\
& Mexico & 141 & 890 & 623 & 389 & 611 & 7520 \\
Exotic/exciting & Iran & 17 & 21 & 50 & 52 & 109 & 1102 \\
\multirow{4}{*}{ Beautiful } & Mexico & 46 & 127 & 103 & 114 & 170 & 2267 \\
& Iran & 4 & 4 & 14 & 24 & 26 & 347 \\
War/invasion/attack & Mexico & 10 & 37 & 15 & 49 & 72 & 739 \\
Human rights & Iran & 371 & 90 & 169 & 406 & 1042 & 7456 \\
& Mexico & 48 & 84 & 57 & 90 & 119 & 304 \\
\multirow{3}{*}{ Terrorism/sanctions } & Iran & 19 & 33 & 77 & 86 & 195 & 1542 \\
& Mexico & 4 & 11 & 21 & 28 & 24 & 333 \\
& Iran & 80 & 84 & 122 & 270 & 974 & 4650 \\
& Mexico & 4 & 25 & 9 & 99 & 33 & 471 \\
\hline
\end{tabular}

